\title{
Acquired hemophagocytic lymphohistiocytosis associated with malignant disease
}

INSERM

\section{Source}

INSERM. (1999). Orphanet: an online rare disease and orphan drug data base. Acquired hemophagocytic lymphohistiocytosis associated with malignant disease. ORPHA:158057

Acquired hemophagocytic lymphohistiocytosis associated with malignant disease is a rare, secondary hemophagocytic lymphohistiocytosis characterized by occurring as either initial presentation of a malignant disease or at any stage during chemotherapy. The common associated malignancies are lukemias, B-cell, T-cell or NK-cell lymphomas, and Hodgkin lymphoma. Typical clinical manifestation includes fever, hepatosplenomegaly and cytopenias, combined with specific laboratory findings. 